\title{
СКАЛА ЗА МЕРЕЊЕ НА ФЯЕКСИБИЯНОСТА НА ОБЛАСТИТЕ РАБОТА И СЕМЕЈСТВО: ПРВИЧНА ПРОЦЕНА НА ПСИХОМЕТРИСКИТЕ КАРАКТЕРИСТИКИ НА ПРИМЕРОК СОСТАВЕН ОД НАСТАВНИЦИ
}

\section{Кратка содржина}

Истражуването на начинот на управуванье со работата и семејството како две различни области станува мошне важно заради зголемениот број семејства со двојна кариера, дигитализацијата и промените во временскиот распоред на работа (флексибилно работно време). Целта на овој труд е да се испитаат психометриските карактеристики на скалата за мерене на флексибилноста на областите работа и семејство во македонски контекст. Примерокот го сочинуваа 200 наставници од основно, средно и високо образование. За проверка на факторската валидност на скалата беше применета експлораторна факторска анализа (метод на факториране главни оски со ртотах ротација), додека за дополнителна проверка на конструкт валидноста беше применет Пирсонов метод на корелација. Релијабилноста на скалата беше оценета врз основа на коефициентите на внатрешна конзистентност. Беа идентификувани 4 фактори: можности за преминуване на границьата на работниот домен, мотивација/желба/подготвеност за преминуване на границата на работниот домен, можности за преминуване на границата на семејниот домен, подготвеност за преминуванье на границата на семејниот домен, согласно со факторскиот модел на оригиналната скала. Исклучок беше еден исказ/ајтем со факторско заситуване на факторот можности за преминуване на границата на работниот домен, наместо на факторот подготвеност за преминуване на границата на работниот домен, како што беше претпоставено. Сите фактори/супскали покажаа задоволителна релијабилност. Генерално, резултатите покажаа дека оваа скала може да се користи за истражувачки цели во нашиот контекст. Неопходни се дополнителни испитуватьа со примена на мултигрупна конфирматорна факторска анализа со цеел да се потврди овој модел и неговата стабилност кај различни групи вработени.

Клучни зборови: флексибилност на границичте, работа и семејство, психометриска процена, факторска структура

Луѓето имаат раздични улоги што ги манифстираат во раздични животни области. Со цел да воспостават ред во овие области и да го поедностават функционирањето во нив, тие поставуваат и одржуваат грани- 
ци и со тоа го дефинираат времето и местото на извршување на улогите (Ashforth et al., 2000). Така, улогата на вработен/а се извршува на работното место, односно во текот на работното време, додека улогата на родител настапува во домот, т.е. надвор од работното време. Имајќи ги предвид работата и семејството, може да се забележи дека луѓето секојдневно ги преминуваат границите на овие две области манифестирајќи сопствен стил на управување со нив (Bulger et al., 2007, Kossek et al., 2012, Sturges, 2012). Општо земено, управувањето со областите работа-семејство може да се сфати како континуум почнувајќи од висока интегрираност придружена со флексибилни и пропустливи граници коишто водат кон преклопување на двете области, па сѐ до висока сегментираност каде границите се нефлексибилни и непропустливи што подразбира јасна одвоеност на работните и на семејните улоги (Allen et al., 2014).

Според тоа, важен аспект на управувањето со границите на работата и семејството како две одделни области е движењето од едната во другата област. Преминувањето од работа дома (физички иди когнитивно) и обратно, се карактеризира со флексибилност и со пропустливост на границата. Додека флексибилноста упатува на степенот на еластичност на границата помеѓу работата и семејството (Allen et al., 2014), пропустливоста е степен до којшто елементи од едниот домен преминуваат во другиот домен (Clark, 2000), но и двете карактеристики ја покажуваат цврстината на границата (Bulger et al., 2007). Метјус и Барнс-Фарел (Matthews \& Barness-Farrell, 2010) сметаат дека флексибилноста на границите помеѓу работата и семејството се манифестира на два начини: преку можностите да се преминува од едниот во другиот домен (work flexibility ability и family flexibility ability) што претставува перципирана можност за движење кон семејната област во текот на работата и можности за посветување на работата во време кога треба да се извршува семејната улога, како и преку подготвеноста/желбата за преминување од едната во другата област (work flexibility willingness and family flexibility willingness) што покажува степен на мотивираност да се исполнуваат семејни обврски во текот на работата и обратно.

Авторите конструираат и скала за мерење на овие аспекти составена од 19 ајтеми коишто дефинираат четири одделни фактори што е во согласност со теоретски претпоставениот модел. Имено, со применетата експлораторна факторска анализа идентификувано е решение со 4 фактори коишто објаснуваат 47 \% од варијансата во споменатиот концепт, додека конфирматорната факторска анализа покажала дека добиениот модел е усогласен со претпоставениот модел. Врз основа на корелациска анализа авторите соопштуваат дека жените се поподготвени од мажите да преминуваат од работниот во семејниот домен, но дека помалку сакаат и помалку можат да преминуваат од семејството кон работата. Исто така, соопштуваат дека важноста на работната улога е позитивно поврзана со подготвеноста семејните активности да се одложат заради обврските на работа и негативно поврзана со подготвеноста да се одложат работните 
задачи заради исполнување на семејните обврски. Нашле и негативна корелација на можностите за флексибилно управување со работниот домен со конфликтот на работата со семејството и конфдиктот на семејството со работата, додека пак, подготвеноста за фиексибилно управување со семејнниот домен корелирала само со конфликтот работа -семејство (Matthews \& Barness-Farrell, 2010).

Метјус и соработниците (Matthews et al., 2010) ја ревидирале првичната верзија на скалата, а наодите од тестирањето на ревидираната скала покажале прифатлива усогласеност на претпоставениот модел. Исто така, најдено е дека конструктот флексибилност на границите на работата и семејството е поврзан со важноста на животните улоги и со актуелните премини (когнитивни и бихејвиорални) помеѓу двете области (Winkel et al., 2010). Попрецизно, двата аспекти, перципирана можност и мотивираност за преминување меѓу областите, биле позитивно поврзани со преминувањето од работа дома, и со преминувањето од семејството кон работата, а пак, преминувањето од дома кон работа позитивно коредирадо само со флексибилноста на семејниот домен (Matthews et al., 2010).

Според Метјус и сор. (Matthews et al., 2010) преминувањето помеѓу областите се однесува на бројот на актуелно транзитирање, когнитивно (на пр. помислување како е или што прави детето дома, размислување за работните задачи што треба да се реализираат) и бихевиорално (на пр. излегување порано од работа за да се исполни некоја семејна обврска, разговор на телефон со сопругот/ата, одговарање службени е-дописи), од едната во другата област. Авторите сметаат дека ваквата операционалзиција на конструктот има подобра теоретска основа од концептот пропустливост на границите помеѓу областите работа и семејство.

Истражувањето на начинот на управување со областите е многу важно за добросостојбата на вработените и за рамнотежата помеѓу работата и другите животни области. Студиите покажуваат дека флексибилноста на семејната област е поврзана со задоволството од животот, особено помеѓу вработени кај кои пропустливоста на границата на семејниот домен е високоизразена (Qiu \& Fan, 2015), дека интеграцијата помеѓу работата и семејството води кон исцрпеност и помал степен на рамнотежа помеѓу работата и другите области (Wepfer et al.,2018), како и дека преферирањето на одвојување на работата и семејството е поврзано со подобро воспоставен баланс помеѓу работата и другите животни области (Mellner et al., 2015).

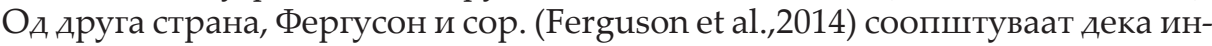
струменталната поддршка од раководителот и поддршката на органзаицијата во сегментирањето на работата и семејниот живот придонесуваат кон перципирана можност за флексибилност на работата, што пак, води кон подобро функционирање на семејството и посилно изразена приврзаност кон организацијата.

Треба да се наведе и дека флексибилноста на границите помеѓу работата и семејството заедно со нивната пропустдивост може да бидат 
значајни за последиците предизвикани од работењето од дома во текот на пандемијата од Ковид-19 (Cho, 2020). Помеѓу позитивните аспекти на работењето од дома заради пандемијата, биле идентификувани флексибилното работно време, поголемата автономија и подобрата рамнотежа помеѓу работата и другите области, додека меѓу негативните карактеристики биле евидентирани дистракцијата и спојувањето на работните и семејните улоги (Vyas \& Butakhieo, 2021). Косек и cop. (Kossek et al.,2020) истакнуваат дека работата од дома (работата на далечина) може да делува поттикнувачки за управувањето на работата и семејните активности, особено кај жените вработени во академската област/универзитет, но и дека може да доведе до заемно попречување на двете области, нарушување на процесот на одвивање на активностите заради потребата од брзо преминување од еден на друг тип обврски, поголема работна достапност, што може да доведе до нарушување на здравјето и функционирањето на семејството, како и до согорување. Овие наоди претставуваат дополнителна причина за испитување на начините/стиловите на управување со работните и семејните активности, а особено флексибилноста и преминувањето помеѓу овие области, со примена на мерни инструменти со проверени психометриски карактеристики.

\section{Цел на истражувањето}

Земајќ́и го предвид издоженото, целта на овој труд беше да се испитаат психометриските карактеристики на мерката/прашалникот за флексибилност на областите работа и семејство и следствено, да се оцени нејзината примендивост во овдешен контекст. Попрецизно, целта беше да се испита конструкт валидноста на оваа скала на примерок наставници во основно, средно и високо образование. Претпоставката беше дека ќе биде идентификувана четирифакторска структура согласно добиениот факторски модел на оригиналната скала. Дополнително беше проверена поврзаноста на идентификуваните фактори со преминувањето помеѓу областите работа - семејство, полот на испитаниците, бројот на деца, брачниот статус и работното место, а со цел понатамошна проверка на конструкт валидноста на скалата. Врз основа на претходните емпириски наоди, беше претпоставено дека аспектите на флексибилноста на работниот домен позитивно ќе корелираат со премините од работниот кон семејниот домен, додека аспектите на флексибилноста на семејната област ќе бидат позитивно поврзани со премините од семејството кон работата. Понатаму, беше претпоставено дека жените, испитаниците кои се во брак и оние кои имаат две деца ќе бидат помалку подготвени и дека ќе ги оценат можностите за воспоставување флексибилни граници на семејната област како помали во споредба со мажите, со колегите кои немаат брачен партнер, и кои имаат едно дете или немаат деца. Исто така, беше претпоставено дека универзитетските професори ќе ги оценат можностите за преминување 
помеѓу областите како поизразени откодку нивните колеги во основно и средно образование, а како резултат на поголемата автономија и флексибилност на распоредот на активности.

\section{Метод}

\section{Примерок и постапка}

Во истражувањето учествуваа 200 наставници (138 жени и 62 мажи) на просечна возраст од 43,29 години (SD = 9.38). Од нив, 115 беа вработени во средно образование, 31 во основно образование и 51 на универзитет. Во брак изјавија дека се 138 учесници во истражувањето, додека 62 соопштија дека не се во брак. Во однос на бројот на деца, 130 испитаници одговориле дека имаат две или повеќе деца, 40 изјавиле дека имаат едно дете, 29 учесници немале деца и 9 испитаници не одговориле на прашањето.

Податоците беа собрани во периодот април - мај, 2018 година. На испитаниците им беше објаснета целта на студијата, беше истакнато дека учеството е анонимно и довердиво, односно дека нема да се сопштуваат поедниечни податоци, туку дека ќе бидат обработени на групно ниво и искористени само за научноистражувачки цели. Пополнувањето на прашалниците траеше околу 15 - 20 минути.

\section{Мерни инструменти}

Прашалникот за флексибилност на областите работа и семејство (Matthews et al., 2010) беше зададен со цел да се процени флексибилноста на границата помеѓу работата и семејството, т.е. можноста за флексибилност на работата (4 ајтеми), подготвеноста за флексибилност на работата (4 ајтеми), можноста за флексибилност на семејството (5 ајтеми) и подготвеноста за флексибилност на семејството (6 ајтеми). Ајтемите беа бодувани на 7-степена скала од Аикертов тип (од 1 - воопшто не се согласувам до 5 - сосема се согласувам). Повисок скор означува поизразена можност и поголема подготвеност за флексибилност на работата, односно семејството.

Авторите на скалата соопштуваат дека конфирматорната факторска анализа покажала добра усогласеност на четирифакторскиот модел. Интерната конзистентност на четирите супскали добиле дека се движи во опсег од 0.74 до 0.86 (Matthews et al., 2010).

Фреквенцијата на преминување од работниот кон семејниот домен и обратно, беше мерена со скалата за премини помеѓу работата и семејството (Matthews et al., 2010) со 11 искази кои се оценуваа на Дикертова скала од 6 степени (од 0 - никогаш до 5 - пет дена во седмицата или повеќе). Шест ајтеми се однесуваа на зачестеноста на актуелните преминувања од работата кон семејството, а останатите 5 ајтеми ја мереа фреквенцијата на пре- 
мини од семејниот кон работниот домен. Повисок скор означува поголем број премини од едниот во другиот домен. Кронбах алфа-релијабилноста, според нејзините автори, изнесува 0.78 за супскалата премини работа - семејство и 0.75 за супскалата премини семејство - работа.

\section{Анализа на податоците}

За проверка на факторската структура на скалата беше спроведена експлораторна факторска анализа (за екстракција на факторите беше применет методот факторирање на главни оски, со promax ротација на добиените фактори). Експдораторната факторска анадиза е посоодветна кога целта е да се испита латентната структура на варијаблите во истражувањето (Hair et al., 2014), додека пак, методот на гдавни оски, освен што е избран како најчесто користен, воедно е поадекватен кога дистрибуцијата на варијаблите отстапува од нормалната (Hair et al., 2014; Osborne, 2014). Косата/дијаголната ротација е повеќе преферирана кога постои теоретска или емпириска основа да се очекува факторите да корелираат помеѓу себе бидејќи во таков случај дава појасни резултати (Fabrigar et al., 1999).

Критериум за извлекување, т.е. идентификување на факторите беше латентен корен (ајген вредност) поголема од 1, а како минимален износ на факторските заситувања за да бидат разгледувани беше дефинирана вредноста 0.32 (Tabachnick \& Fidell, 2013), т.е. околу 10 \% споделена варијанса. Коефициентите на корелација помеѓу ајтемите/варијаблите, антиимиџ матрицата и мерката за адекватност на мострењето (MSA) беа земени предвид при оценување на примендивоста на факторската анализа.

\section{Резудтати}

Мерката на мострењето (Kaiser-Meyer-Olkin) се доби дека изнесува .84 што покажува дека податоците се соодветни за примена на факторска анализа. Бартлетовиот тест на сферичност беше статистички значаен $\left(\chi^{2}=1779.18, \mathrm{df}=171, \mathrm{p}<.001\right)$ укажувајќи дека корелацијата помеѓу ајтемите/ варијаблите е доволно висока за да се спроведе факторска анализа. Дополнително, увидот во матрицата на корелации покажа дека повеќето имаат износ над 0.30 (повисоките коефициенти на корелација беа карактеристични за оние ајтеми каде и се очекуваше нивната поврзаност), а антиимиџ матрицата покажа дека парцијалните коефициенти на корелација помеѓу ајтемите се ниски.

Беа добиени четири фактори со ајген вредност повисока од 1 кои објаснуваа 54 \% од варијансата на конструктот флексибилност на границите. Продуцираниот скатер-плот го поддржа ова факторско решение. Идентификуваниот факторски модел заедно со факторските заситувања, комуналитетите и пропорцијата на објаснета варијанса од страна на секој фактор поединечно, се дадени во табела 1. 
Табела 1

Факторски заситуваюа, заедничка варијанса и биваријатна корелација помеѓу идентификуваните фактори

\begin{tabular}{|c|c|c|c|c|c|}
\hline & $\begin{array}{l}\text { Ф1-мож- } \\
\text { ности за } \\
\text { премину- } \\
\text { вање на } \\
\text { границата } \\
\text { на ра- } \\
\text { ботниот } \\
\text { домен }\end{array}$ & $\begin{array}{l}\text { Ф2-под- } \\
\text { готвеност } \\
\text { за преми- } \\
\text { нување } \\
\text { на грани- } \\
\text { цата на } \\
\text { семејниот } \\
\text { домен } \\
\end{array}$ & $\begin{array}{l}\text { Ф3-мож- } \\
\text { ности за } \\
\text { преми- } \\
\text { нување } \\
\text { на грани- } \\
\text { цата на } \\
\text { семејниот } \\
\text { домен } \\
\end{array}$ & $\begin{array}{l}\text { Ф4-под- } \\
\text { готвеност } \\
\text { за преми- } \\
\text { нување на } \\
\text { границата } \\
\text { на ра- } \\
\text { ботниот } \\
\text { домен } \\
\end{array}$ & $\begin{array}{l}\text { ва- } \\
\text { ријанса }\end{array}$ \\
\hline Ајтем 3 & .797 & & & & .637 \\
\hline Ајтем 4 & .737 & & & & .576 \\
\hline Ајтем 2 & .716 & & & & .544 \\
\hline Ајтем 1 & .707 & & & & .507 \\
\hline Ајтем 6 & .668 & & & & .607 \\
\hline Ајтем 5 & .504 & & & .417 & .520 \\
\hline Ајтем 17 & & .920 & & & .771 \\
\hline Ајтем 18 & & .806 & & & .598 \\
\hline Ајтем 15 & & .764 & & & .570 \\
\hline Ајтем 14 & & .734 & & & .669 \\
\hline Ајтем 16 & & .703 & & & .517 \\
\hline Ајтем 19 & & .508 & & & .295 \\
\hline Ајтем 11 & & & .805 & & .639 \\
\hline Ајтем 10 & & & .651 & & .384 \\
\hline Ајтем 13 & & & .588 & & .559 \\
\hline Ајтем 9 & & & .563 & & .262 \\
\hline Ајтем 12 & & .342 & .374 & & .585 \\
\hline Ајтем 8 & & & & .643 & .650 \\
\hline Ајтем 7 & & & & .534 & .450 \\
\hline $\begin{array}{l}\text { \% на } \\
\text { објас- } \\
\text { нета ва- } \\
\text { ријанса }\end{array}$ & 22.81 & 20.65 & 6.61 & 4.35 & \\
\hline Фактор 1 & - & -.092 & .103 & $.631^{* * *}$ & \\
\hline Фактор 2 & & - & $.419^{* * *}$ & -.076 & \\
\hline Фактор 3 & & & - & .069 & \\
\hline Фактор 4 & & & & - & \\
\hline
\end{tabular}

Првиот фактор го сочинуваа ајтемите конструирани за мерење на перципираните можности за преминување на работниот домен, вториот фактор беше добиено дека е дефиниран преку ајтемите наменети за мерење на подготвеноста за флексибилно однесување во рамките на семејниот домен, ајтемите преку коишто се оценуваат перципираните можности 
за флексибилност во рамките на семејниот домен го сочинуваа третиот идентификуван фактор, и најпосле, ајтемите за оценување на перципираните можности за флексибилност во областа на работата беа репрезенти на четвртиот фактор.

Како што може да се види, сите фактори се составени од најмалку 3 ајтеми и најголем дел од факторските заситувања имаат вредност над 0.60 што означува 36 \% или повеќе споделена варијанса на конкретните ајтемите со факторот што го дефинираат. Попрецизно, ротираната матрица покажа јасно факторско решение, но притоа, неопходно е да се наведе дека два ајтеми (5 и 12) припаѓаат и на два други фактори. Сепак, имајќи ја предвид нивната содржина, тие се задржани на првичните фактори, т.е. фактор 4 и фактор 3, соодветно). Исклучок овде, во овој модел, е што ајтем 6 покажа заситување со друг фактор наместо со факторот како што е претходно добиено. Оттука, неопходно е овој резудтат понатаму да се провери.

Биваријатната корелациска анализа покажа дека двата фактори/аспекти на флексибилноста на работата се силно поврзани, при што беше најдено дека не постои колинеарност помеѓу нив (толеранцијата имаше вредност над 0.40, којашто, како што е наведено кај Mayers et al., 2013, се смета за гранична). Поврзаноста помеѓу факторите/ аспектите на флексибидноста на семејниот домен беше умерено изразена. Меѓусебно, факторите од двата домени беше добиено дека не се значајно поврзани.

Табела 2 покажува дека кај учесниците во истражувањето највисоко е изразена перципираната можност за флексибилно однесување кога станува збор за семејниот домен, а најнизок степен на изразеност има перципираната можност за флексибилност на областа работа. Доколку податоците се споредат со средната вредност на скалата, а тоа е 4 (опсег од 1 до 7), може да се заклучи дека можноста за премини од работниот кон семејниот домен е виддиво под просекот, додека можноста за движење во обратната насока е релативно високоизразена. Дополнително, t-тестот за изедначени групи покажа дека оваа раздика е статистички значајна $(t(199)=14.66$, $\mathrm{p}<.001)$. Мотивацијата за премини од работа дома и обратно од семејството кон работниот домен, како што покажуваат наодите, е просечно изразена. Дополнително, добиената раздика во изразеноста на овие два аспекти не е статистички значајна $(\mathrm{t}(199)=1.35, \mathrm{p}>.05)$. 
Табела 2

Дескриптивни статистиции и релијабилност на екстахираните фактори

\begin{tabular}{|l|l|l|l|l|l|l|}
\hline & M & SD & Sk & Kk & $\begin{array}{l}\text { Min/ } \\
\text { max }\end{array}$ & $\begin{array}{l}\text { Cronbach } \\
\text { alpha }\end{array}$ \\
\hline $\begin{array}{l}\text { можности за } \\
\text { преминување на } \\
\text { границата на ра- } \\
\text { ботниот домен }\end{array}$ & 3.17 & 1.54 & .56 & -.53 & $1 / 7$ & .86 \\
\hline $\begin{array}{l}\text { подготвеност за } \\
\text { преминување на } \\
\text { границата на ра- } \\
\text { ботниот домен }\end{array}$ & 4.05 & 1.53 & -.21 & -.73 & $1-7$ & .76 \\
\hline $\begin{array}{l}\text { можности за } \\
\text { преминување } \\
\text { на границата на } \\
\text { семејниот домен }\end{array}$ & 5.05 & 1.12 & -.84 & .52 & $1.2 / 7$ & .75 \\
\hline $\begin{array}{l}\text { подготвеност за } \\
\text { преминување } \\
\text { на границата на } \\
\text { семејниот домен }\end{array}$ & 4.25 & 1.29 & -.36 & -.32 & $1 / 7$ & .86 \\
\hline
\end{tabular}

Анализираната корелација помеѓу аспектите на флексибилноста на областите работа и семејство покажа дека учесниците во истражувањето кои сметаат дека можат да бидат флексибилни, но и кои покажуваат подготвеност за тоа кога станува збор за работата, почесто преминуваат, когнитивно или физички, од работниот кон семејниот домен (r=.60, p<.001 и $\mathrm{r}=.48, \mathrm{p}<.001$, соодветно). Покрај тоа, беше најдено дека овие два аспекти се позитивно поврзани и со зачестеноста на актуелните премини од семејството кон работниот домен, иако виддиво послабо ( $\mathrm{r}=.27, \mathrm{p}<.001$ и r=.17, $\mathrm{p}<.05$, соодветно). Понатаму, испитаниците кои манифестираат погодема подготвеност да бидат флексибилни со своите семејни обврски и активности, и кои изјавуваат дека имаат можности за флексибилност кога станува збор за семејната улога, соопштуваат повисок број актуелни премини, на когнитивно ниво или физички, од семејниот домен кон работниот, но и оваа заемна врска не е силна ( $\mathrm{r}=.14, \mathrm{p}<.05$ и $\mathrm{r}=.18, \mathrm{p}<.01$, соодветно).

Во однос на половите раздики, најдено е дека мажите сметаат дека имаат поголеми можности за флексибилност на работните обврски $(\mathrm{M}=3.74)$ отколку жените $(\mathrm{M}=2.92),(\mathrm{t}(198)=3.58, \mathrm{p}<.001)$. Исто така, тие покажуваат и поизразена подготвеност за флексибилност во семејниот домен (M=4.64) во споредба со нивните колешки (M=3.79), (t(198)=3.74, $\mathrm{p}<.001)$. Полови раздики во поглед на другите два аспекти не беа регистрирани. Без разлика на бројот на деца и брачниот статус, не беа најдени раздики во изразеноста на четирите аспекти на флексибилноста на работниот и се- 
мејниот домен. Возраста на испитаниците покажа значајна позитивна, но слаба поврзаност со мотивацијата за преминување од семејната кон работната област $(\mathrm{r}=.18, \mathrm{p}<.05)$.

\section{Дискусија}

Во овој труд беа проверени психометриските карактеристики на прашалникот на флексибилност на областите работа и семејство, конструирана од Метјус и неговите соработници (Matthews et al., 2010) во македонски контекст. Соодветно на тоа, првичната процена на карактеристиките ја потврдија можноста за нејзина употреба во истражувачки цели во областа на психологијата на трудот и организацијата.

Конзистентно на предложениот теоретски модел и резултатите од факторската анадизата соопштени од авторите на скалата, експлораторната факторска анализа (факторирање на главни оски со коса ротација од типот промакс) применета во ова истражување откри четирифакторско решение. Таквиот резултат е во прилог на факторска валидност на скалата. Сите четири фактори покажаа задоволителна релијабилност/интерна конзистентност.

Идентификуваните фактори во работниот домен - можност и подготвеност за флексибилност на работните улоги, од една страна, и добиените фактори во семејниот домен - можност и подготвеност за флексибилност на семејните улоги, од друга страна, покажаа релативно висока корелација. Можеби може да се смета за очекувано дека вработените кои мислат дека имаат можности да го променат распоредот на работните задачи и работното време или да земат слободен ден, ќе имаат погодема мотивација да направат движења од работниот во семејниот домен со цел да ги исполнат семејните одговорности. Слично на тоа, вработените кои сметаат дека се во можност да ги променат плановите во врска со домашните активности, да одложат семејни обврски, ќе покажат и поголема мотивираност за флексибилност на семејната улога. Соодветно на тоа, резултатите се во согласност со претпоставката дека флексибилноста и на работниот и на семејниот домен, како карактеристики на управувањето со границите помеѓу нив, имаат два посебни аспекти - перципирана можност за движења од еден до друг домен и изразена подготвеност за преминување помеѓу домените. Отсуството на корелација на способноста и подготвеноста за работна флексибилност со способноста и подготвеноста за флексибилност во семејството, може да се смета како емпириска потврда дека двете области, работата и семејството се раздични, со сопствени граници (Matthews \& Barnes-Farrell, 2010).

Како што беше соопштено, искиучок од претходно идентификуваниот модел беше наодот според којшто ајтемот 6 (, под претпоставка дека сѐ е во ред со мојот претпоставен, не би имал ништо против да пристигнам на работа доцна за да можам да ги исполнам моите семејни и лични одговорности“) 
покажа заситување со факторот 1 -перципирана можност за флексибилност на работниот домен, наместо со фактор 4 - подготвеност за флексибилност на работниот домен. Земајќи го предвид првиот дел од неговата содржина, можно е тоа да било сфатено како показател на можноста за флексибилност на работната улога и задачите кои од неа произлегуваат, особено бидејќи таквите можности се детерминирани од организациските правила и подитики. Другата можност е, при одговарањето на исказот, тој да имплицирал на двата аспекти. Затоа, потребно е понатамошно разгледување на овој ајтем во насока на ревидирање на содржината или пак, добивање нови наоди со кои би се потврдила неговата припадност на посочениот фактор/аспект.

Значајната поврзаност на аспектите на флексибилноста на работата и факторите на флексибилноста на семејството со актуелните премини од работа во семејство, како и од семејството кон работата, може да се смета како дополнителна поддршка на конструкт валидноста на скалата. Овие резултати се во согласност со претходните наоди (Matthews et al., 2010, Winkel \& Clayton, 2010). Отсуството на значајна корелација на аспектите на флексибилноста на работниот и семејниот домен со брачниот статус и бројот на деца веројатно подразбира дека испитаните карактеристики на управувањето со границите, особено оние од областа на работата, се повеќе условени од факторите поврзани со организацијата и работата отколку од семејството и/иди индивидуални фактори. Во контекст на претходно наведеното, работното место е поврзано со флексибилноста на работниот домен, односно перципираната можност и мотивираност да се премине од работата во семејството. Поконкретно, тие беа највисоко изразени кај универзитетските наставници во споредба со наставниците од средно и основно училиште. Не беа пронајдени значајни раздики во можноста и подготвеноста за флексибилност на семејниот домен кај трите групи испитаници. Имено, овој наод може да се објасни со поголема автономија при планирање и (ре)организирање на дел од работните активности и повисок степен на временска флексибилност како карактеристики поприсутни на универзитетско ниво. На пример, откриено е дека индивидуално-ориентираната временска флексибилност води кон поголема контрола на границите и придонесува за рамнотежа помеѓу работата и семејството (Wöhrmann et al., 2021). Покрај тоа, регистрираните полови раздики во однос на перципираната можност и подготвеноста за флексибилност на работата може да се објаснат и од аспект на наодите дека вработените мажи со семејни обврски се сметаат за постабилни и одговорни, додека на вработените жени се гледа како повеќе посветени на семејството отколку на работата (Greenhaus et al., 2010). Земени заедно, гореспоменатите резултати имплицираат дека работните и семејните домени се раздичн и дека вработените демонстрираат раздичен однос кон карактеристиките на границите на тие области. 
Конечно, може да се заклучи дека е потребно понатамошно испитување на факторската структура на мерката за флексибилност на областите на работата и семејството со употреба на конфирматорна факторска анализа (CFA). Особено, треба да се примени мултигрупна CFA со цел да се потврди стабилноста на скалата кај раздични групи вработени и од разпични сектори.

Сепак, резултатите за психометриските карактеристики на оваа мерка добиени во спроведената студија одат во придог на нејзината примена во овдешен контекст. Воедно, упатуваат на потребата за истражување на флексибилноста на работниот и семејниот домен, како и испитувањето на управувањето со границите, воопшто, што може да придонесе кон нови емпириски резултати и разбирање на заемниот однос помеѓу работата и семејството и нејзината улога во благосостојбата на вработените и работната перформанса. Секако, покрај семејството, предвид треба да се земат и другите животни области, како на пример слободните активности, пријателите. 


\section{Литература}

Allen, T. D., Cho, E., Laurenz L. Meier, L. L. (2014). Wirk-family boundary dynamics. Annual Review of Organizational Psychology and Organizational Behavior, 1(1), 99-121. https://doi.org/10.1146/annurev-orgpsych-031413-091330

Ashforth, B. E., Kreiner, G. E., \& Fugate, M. (2000). All in a day's work: Boundaries and micro role transitions. Academy of Management Review, 25(3), 472-491. https://doi.org/10.5465/AMR.2000.3363315

Bulger, C. A., Matthews, R. A., \& Hoffman, M. E. (2007). Work and personal life boundary management: Boundary strength, work/personal life balance, and the segmentation-integration continuum. Journal of Occupational Health Psychology, 12(4), 365-375. https://doi.org/10.1037/1076-8998.12.4.365

Clark, S. C. (2000). Work/family border theory: A new theory of work/ family balance. Human Relations, 53(6), 747-770. https://doi. org/10.1177/0018726700536001

Cho, E. (2020). Examining boundaries to understand the impact of COVID-19 on vocational behaviors. Journal of Vocational Behavior, 119, 103437. https://doi.org/10.1016/j.jvb.2020.103437

Fabrigar, L. R., Wegener, D. T., MacCallum, R. C., \& Strahan, E. J. (1999). Evaluating the use of exploratory factor analysis in psychological research. Psychological Methods, 4(3), 272-299. https://doi.org/10.1037/1082-989X.4.3.272

Ferguson, M., Carlson, D. and Kacmar, K.M. (2015), Flexing work boundaries: The spillover and crossover of workplace support. Personnel Psychology, 68(3), 581-614.

https://doi.org/10.1111/peps.12084

Greenhaus, J. H., Callanan, G. A., \& Godshalk, V. M. (2010). Career management. Sage.

Hair Jr. J. F., Black, W. C., Babin, B. J., Rolph E. Anderson, R. E. (2014). Multivariate Data Analysis ( $7^{\text {th }} \mathrm{ed}$.). Pearson.

Kossek, E. E., Allen, T. D., \& Dumas, T. L. (2020). Boundaryless work: The impact of COVID-19 on work-life boundary management, integration, and gendered divisions of labor for academic women in STEMM.

https://www.nap.edu/resource/26061/Kossek\%20et\%20al\%20-\%20 FINAL.pdf

Kossek, E. E., Ruderman, M. N., Braddy, P. W., \& Hannum, K. M. (2012). Work-nonwork boundary management profiles: A person-centered approach. Journal of Vocational Behavior, 81(1), 112-128.

https://doi.org/10.1016/j.jvb.2012.04.003 
Matthews, R. A., \& Barnes-Farrell, J. L. (2010). Development and initial evaluation of an enhanced measure of boundary flexibility for the work and family domains. Journal of Occupational Health Psychology, 15(3), 330346. https://doi.org/10.1037/a0019302

Matthews, R. A., Barnes-Farrell, J. L., \& Bulger, C. A. (2010). Advancing measurement of work and family domain boundary characteristics. Journal of Vocational Behavior, 77(3), 447-460. https://doi.org/10.1016/j. jvb.2010.05.008

Mayers, L. S., Gamst, G., \& Guarino, A. J. (2013). Applied multivariate research (2 ${ }^{\text {nd }}$ ed.). Sage.

Mellner, C., Aronsson, G., \& Kecklund, G. (2015). Boundary management preferences, boundary control, and work-life balance among full-time employed professionals in knowledge-intensive, flexible work. Nordic Journal of Working Life Studies, 4(4), 7-23. https://doi.org/10.19154/njwls. $\mathrm{v} 4 \mathrm{i} 4.4705$

Osborne, J. W. (2014). Best Practices in Exploratory Factor Analysis. CreateSpace Independent Publishing.

Qiu, L., \& Fan, J. (2015). Family boundary characteristics, work-family conflict and life satisfaction: A moderated mediation model. International journal of psychology, 50(5), 336-344. https://doi.org/10.1002/ijop.12107

Sturges, J. (2012). Crafting a balance between work and home. Human Relations, 65(12), 1539-1559. https://doi.org/10.1177/0018726712457435

Tabachnick, B. G., \& Linda S. Fidell, L. S. (2013). Using Multivariate Statistics (6 ${ }^{\text {th }}$ ed.). Pearson.

Wepfer, Ariane G; Allen, Tammy D; Brauchli, Rebecca; Jenny, Gregor J; Bauer, Georg F (2018). Worklife boundaries and well-being: does work-tolife integration impair well-being through lack of recovery? Journal of Business and Psychology, 33(6):727-740. https://doi.org/10.1007/s10869-017-9520-y

Winkel, D. E. \& Clayton, R. W. (2010). Transitioning between work and family roles as a function of boundary flexibility and role salience. Journal of Vocational Behavior, 76(2), 336-343. https://doi.org/10.1016/j.jvb.2009.10.011

Wöhrmann, A.M., Dilchert, N. \& Michel, A. (2021). Working time flexibility and work-life balance. Zeitschrift für Arbeitswissenschaft, 75, 74-85 (2021). https://doi.org/10.1007/s41449-020-00230-x

Vyas, L. \& Butakhieo, N. (2021) The impact of working from home during COVID-19 on work and life domains: an exploratory study on Hong Kong. Policy Design and Practice, 4(1), 59-76. https://doi.org/10.1080/257 41292.2020.1863560 